\title{
Trajectories, Traditions, and Tools in Analytic Theology
}

\author{
William Wood \\ Oriel College, Oxford
}

\begin{abstract}
Analytic theology as currently practiced has an ambiguous character. It may be understood either formally, as any instance of theology that draws on analytic philosophy, or substantively, as a cohesive theological school that draws on analytic philosophy in defense of traditional Christian orthodoxy. Both conceptions assume that analytic philosophy furnishes "tools and methods" to the analytic theologian. Yet on the best recent accounts of analytic philosophy, analytic philosophy has no unique tools and methods. I argue that analytic philosophy should be understood as a robust and distinctive intellectual tradition. This understanding of analytic philosophy raises a worry for the emerging field of analytic theology, however: that analytic theologians might be more deeply grounded in the analytic philosophical tradition than in any tradition of theology.
\end{abstract}

\section{Introduction}

When people ask me what analytic theology is, I sometimes say that it is "theology done under the influence of analytic philosophy." That sets me up to joke that analytic philosophy sounds like some kind of mind-altering drug. When I'm not going for cheap laughs, though, I often say that analytic theology is theology that uses the "tools and methods" of analytic philosophy. Here "analytic" theology is just theology that draws on a specific form of philosophy, as other forms of theology also draw on other forms of philosophy. At the same time, however, I also frequently get questions (especially from other theologians) like "Why do analytic theologians have such conservative theological views?" Or "why do analytic theologians ignore historical critical biblical studies?" My usual response is again to appeal to the fact that analytic theology, properly understood, is a way of doing theology - a method-and not a substantive theological program. From this fact, it then supposedly follows that we cannot really make true generalizations about what "analytic theologians" as such affirm. While I do think that this response is fair, I must admit that it also has the whiff of a dodge. Many self-identified analytic theologians do have conservative theological views, and they do tend to ignore historical critical biblical studies, and, in general, they do share a wide range of theological assumptions. These are stereotypes, perhaps, but they are not inapt. Opponents of analytic theology are not unreasonable to think that it is a substantive theological program, and not unreasonable to raise questions about aspects of that program.

It seems, then, that analytic theology as currently practiced has an ambiguous character. On one understanding, "analytic theology" describes any form of theology that

Journal of Analytic Theology, Vol. 4, May 2016

DOI

(C)2016 William Wood • (C) 2016 Journal of Analytic Theology 
draws on analytic philosophy, in the service of any theological agenda whatsoever. Here analytic philosophy furnishes theologians with a set of distinctive conceptual tools and methods of inquiry. Theologians start doing "analytic" theology when they pick up these tools and methods. Call this the "formal model" of analytic theology. On the formal model, a theologian does not need to adhere to any substantive theological or philosophical views in order to count as an analytic theologian. She only needs to explicate whatever substantive views she does hold using the tools and methods of analytic philosophy.

On a different understanding, however, "analytic theology" describes a substantive theological program: theology that draws on the tools and methods of analytic philosophy to advance a specific theological agenda, one that is, broadly speaking, associated with traditional Christian orthodoxy. On this conception, the central task of analytic theology is to develop philosophically well-grounded accounts of traditional Christian doctrines like the trinity, Christology, and the atonement. For the most part, analytic theologians address these doctrines not from any specific confessional or ecclesial standpoint, but from a position that aims to be broadly orthodox. To be sure, some analytic theologians avowedly do write from within a confessional tradition. Nevertheless, because their work is usually grounded in philosophical arguments that are in principle accessible to all, rather than in appeals to narrowly confessional authority, their theology bids for cross-confessional interest. Call this the "substantive model" of analytic theology.

Even though the formal model and the substantive model differ in the way they construe the task of theology, they appeal to the same underlying picture of analytic philosophy, and they presuppose the same underlying relationship between theology and philosophy. On both the formal model and the substantive model, the analytic theologian draws on the "tools and methods" of analytic philosophy. They differ only as to the theological purpose for which those tools and methods are deployed. Call this underlying picture of analytic philosophy-analytic philosophy as tool-the "tool metaphor." Analytic theologians of all stripes accept the tool metaphor.

Interestingly, however-as we shall see- the best recent accounts of analytic philosophy tend to shy away from assertions that analytic philosophy has any distinctive tools and methods. For example, it is clear that analytic philosophers as such are no longer primarily in the business of analyzing concepts or linguistic structures, nor do they typically seek necessary and sufficient conditions for applying terms correctly. ${ }^{1}$ If analytic philosophy no longer features any distinctive tools and methods, however, then what is left of the underlying metaphor that governs both the formal and the substantive models of analytic theology? We should not take this question lightly.

Nor should we try to demarcate analytic philosophy from other forms of inquiry by appealing to its supposedly distinctive tools and methods. (Analytic philosophy has tools and methods, of course, but they are not distinctive to analytic philosophy.) Instead, we should treat analytic philosophy as a distinctive intellectual tradition-in the sense of "tradition" associated with the work of Alasdair MacIntyre. What is distinctive about analytic philosophy is not its tools and methods, but the ways in which one is trained to use

\footnotetext{
${ }^{1}$ For a useful account of recent developments in analytic philosophy, see Timothy Williamson (2014), 'How Did We Get Here From There? The Transformation of Analytic Philosophy,' and Nicholas Wolterstorff (2009) "How Philosophical Theology Became Possible within the Analytic Tradition of Philosophy" in Crisp and Rea 2009, 155-170.
} 
its tools and methods. Because analytic philosophy is a deep and rich intellectual tradition in its own right, one can only learn to use its tools and methods properly by becoming a full member of the analytic tradition.

This account of analytic philosophy, as a MacIntyrean tradition of inquiry, raises a worry for the emerging field of analytic theology, however. In order to practice Christian theology skillfully, one must be similarly steeped in its (often very different) intellectual traditions. The worry is that analytic theologians will be more deeply grounded in the analytic philosophical tradition than in any tradition of theology. In that case, analytic philosophy would no longer furnish tools and methods to the theologian. Rather, theology would furnish specifically Christian puzzles to the analytic philosopher, and the ancient conception of philosophy as the servant of theology would be reversed.

\section{The future of analytic theology: two trajectories}

The distinction I have drawn between the formal and the substantive models of analytic theology can be found even in the original Analytic Theology collection. Consider, first, Michael Rea's original definition of analytic theology in his widely-praised introduction to that collection. According to philosopher Rea, "analytic theology is just the activity of approaching theological topics with the ambitions of an analytic philosopher and in a style that conforms to the prescriptions that are distinctive of analytic philosophical discourse" (Crisp and Rea, 2009, 7). ${ }^{2}$

Rea's definition is purely formal: in principle, any theological topic could be approached with analytic ambitions and addressed in an analytic style. Rea makes no mention of specifically Christian theology, let alone any appeal to a normative Christian tradition. On this understanding, it would be difficult to distinguish analytic theology from philosophical theology. Indeed, on this understanding, it appears that an atheist could do analytic theology. After all, one could approach theological topics with the ambitions and style of an analytic philosopher without oneself affirming that any of the theological claims under discussion are actually true. (This definition therefore invites questions about whether analytic theology is sufficiently distinct from philosophical theology or the philosophy of religion. If an atheist can be an analytic theologian, then can analytic theology really be theology at all?) ${ }^{3}$

As a rhetorical move, it makes sense that defenders of analytic theology would emphasize the formal model. The analytic theologian can appear broad-minded, and analytic philosophy can appear unthreatening, since, on the formal model, analytic philosophy is just another method that can be adapted to theology, like hermeneutics, deconstruction, or phenomenology. When an analytic theologian appeals to this model, he

\footnotetext{
2 For critical discussion of the "analytic style" see Leiter 2004, 11-12; Glock 2008, 152-53, 168-74; Wood 2009, 948-49.

${ }^{3}$ Several of the initial reviews of the original Analytic Theology volume raised questions about how analytic theology can be distinguished from philosophical theology. See, for instance Gordon Graham's review in Notre Dame Philosophical Reviews (2009). Similarly Simon Oliver $(2010,475)$ asks "is analytic theology truly theological? Having read this volume, this remains unclear... The 'philosophy of theology' is no more 'theology' than 'the philosophy of science' is 'science'."
} 
therefore also appeals to the wider methodological pluralism that already flourishes in theology. He simply asks for a bit of room at the table for those who deploy the tools of analytic philosophy instead of those of phenomenology or deconstruction. Academic theology is a broad church, and it has room for many methods.

The formal model of analytic theology also accords with some of our basic intuitions about the relationship between analytic philosophy and analytic theology. Consider a thought-experiment. Suppose that various Barthian, Tillichian, and process theologians suddenly decide to explicate their theological views by using the tools of analytic philosophy. (For example, an "analytic Tillichian" would give an analytic account of God as the ground of being, sin as estrangement, Christ as the New Being, and other Tillichian topoi.) Would we say that such a scenario is impossible or incoherent? I do not think so. Rather we would simply recognize that analytic theists can hold a variety of different theological views, from which it follows that analytic theology can take a variety of substantive forms. Alternatively, imagine the situation in which everyone who is currently sympathetic to analytic theology suddenly becomes convinced that traditional Christian orthodoxy is false and that some form of deism is true. (Let us further suppose that they defend their new deist views with a forest of numbered propositions and a flurry of citations to David Lewis.) What would we say then? Would we say that analytic theology is defunct, and that there are no more analytic theologians? Again, I do not think so. Rather, we would say that analytic theologians now defend unorthodox accounts of God. It seems clear, then, that analytic theology can be understood as a method, a way of doing theology, that could in principle be used in the service of any theological program.

By contrast, consider now another definition of analytic theology, also offered in the original 2009 collection, by theologian William J. Abraham. Abraham's definition is notably different. According to Abraham, analytic theology is "systematic theology attuned to the deployment of the skills, resources, and virtues of analytic philosophy. It is the articulation of the central themes of Christian teaching illuminated by the best insights of analytic philosophy" (Crisp and Rea, 54). Abraham's definition is more substantive, and more theological, than Rea's. As Abraham understands it, analytic theology is specifically Christian systematic theology that articulates "the central themes of Christian teaching" in an analytic idiom. Perhaps wisely, Abraham is vague about the exact nature of that idiom, and about what the "skills, resources, and virtues of analytic philosophy" actually are. (We could also quibble about what exactly it means to "articulate" the central themes of Christian teaching, but in context, I think Abraham means something normative, like "assert and defend.")

Abraham's definition is an example of what I have called the substantive model of analytic theology. While it is true that in principle a theologian could use analytic philosophy in the service of any theological agenda, in fact analytic theology as it is actually practiced seems to advance a very specific theological agenda. Self-described analytic theologians seem especially keen to defend the rationality of traditional Christian orthodoxy. ${ }^{4}$ Likewise, compared to other academic theologians, they do indeed seem to

\footnotetext{
${ }^{4}$ For example, William Hasker's Metaphysics and the Tripersonal God (2013) and Thomas H. McCall's Which Trinity? Whose Monothesim? (2010) both explicitly aim at creedal orthodoxy. Analytic "philosophical theology" has similarly aimed at furnishing broadly orthodox solutions to various problems in Christian
} 
draw on the Bible in a way that is mostly innocent of historical-critical biblical scholarship, and they frequently seem exasperated with modern, postmodern, and revisionist theology. ${ }^{5}$ On the whole, they appear to have little use for the apophatic tradition, so central to Patristic and medieval theology, even as they profess fidelity with Patristic and medieval theology in the same breath. ${ }^{6}$ (In analytic circles, one sometimes hears the assertion that apophatic theology is just "atheism with incense," for example.)

In part, this state of affairs is explained by sociological factors. ${ }^{7}$ Most self-identified analytic theologians are, by training, analytic philosophers of religion, and according to the best data we have, most analytic philosophers of religion are also committed Christians. ${ }^{8}$ Although theists remain a minority in philosophy departments, analytic philosophy of religion has become a natural entry-point for theists-especially Christian theists-who want their religious commitments to shape their academic work. Analytic theology is very obviously a product of a specific intellectual milieu, and its leading advocates are bound together by a variety of educational, professional, and personal ties. They are products of institutions like the University of Notre Dame, Calvin College, Baylor, St. Louewis University, or Biola, along with a similarly well-defined list of evangelical seminaries. They are likely to be members of the Society of Christian Philosophers. They attend the same conferences and network with the same people. It is therefore not just a coincidence that most analytic theologians are broadly orthodox, or theological realists, or fans of univocity. It is not surprising that they tend to read similar texts and address similar problems. It would be foolish to deny that analytic theologians share so many substantive views in part because of sociological facts like these. Analytic theologians share similar views, come from similar religious backgrounds, and work in similar institutional settings. It is therefore not unreasonable for outside observers to assume that analytic theology is_a substantive theological program.

Taken together, the formal and the substantive models of analytic theology stand in a certain tension, and seven years after the original Analytic Theology volume, it is useful to

doctrine. Much of that work might now be called "analytic theology." See Feenstra and Plantinga, Jr., eds., 1989; Rea, ed., 2009; Crisp, ed., 2009; Marmodoro and Hill, eds., 2011.

${ }^{5}$ As a quick example, Hasker $(2013,191-2)$ appeals to the opening verse of the Gospel of John as scriptural evidence that "is God" expresses "the property of being divine." His discussion is confined to that single verse, comprises one paragraph of his own text, and cites only three New Testament scholars, two writing in the 1960 s, the other in the early 1980s. My point here is not that Hasker is incorrect or guilty of shoddy scholarship. My point is that few contemporary academic theologians would believe that Hasker's treatment suffices to show that "we have as good a precedent as could be imagined" for the proposal to treat divinity as a property.

${ }^{6}$ Jacobs $(2015)$ is, so far, a notable exception. Richard Cross $(2010,455)$ usefully warns us not to overstate the degree to which patristic apophaticism is incompatible with analytic theology.

7 I say "in part" because of course an appeal to sociological explanations does not foreclose the possibility that analytic theologians tend to affirm similar views because those views are the ones best supported by argument and evidence. I also think that it would be very interesting to investigate why Christian orthodoxy seems comparatively attractive to analytic philosophers of religion, but that is beyond the scope of this paper. ${ }^{8} \mathrm{On}$ the best data that we have, approximately 70 percent of philosophers of religion are theists, and about 58 percent identify as Christians. By contrast, among philosophers in general, about 73 percent identify as atheists. See the research of Helen de Cruz at http://prosblogion.ektopos.com/2013/12/31/results-of-myqualitative-study-of-attitudes-and-religious-motivations-of-philosophers-of-religion/ and the research of David Bourget and David Chalmers at http://fragments.consc.net/djc/2010/11/more-philpapers-surveyresults.html 
ask which description now seems more apt. In that light, consider a third definition, offered by the Oxford University Press's ever-growing "Analytic Theology" series. According to (presumably) series editors Oliver Crisp and Michael Rea, analytic theology "utilizes the tools and methods of contemporary analytic philosophy for the purposes of constructive Christian theology, paying attention to the Christian tradition and the development of doctrine." This definition is significantly different from Rea's original definition (above). On this definition, analytic theology is specifically Christian, specifically constructive, and specifically tradition-bound. (The definition does not specify that analytic theology must regard the tradition as normative, however.) When we consider these three definitions together, alongside the theological work that is actually being produced under the heading of "analytic theology", it is evident that analytic theology continues to move away from its origins in philosophy of religion and may well be evolving into a distinctive 'school' of Christian theology. It appears that the substantive model is emerging victorious.

\section{Just what are the 'tools and methods' of Analytic Philosophy?}

The formal model and the substantive model offer two different ways of understanding analytic theology, but they both affirm the same relationship between theology and philosophy. They both treat analytic philosophy as a tool for theologians. They differ only according to the purposes for which that tool is used. In the formal model, any kind of theology can count as analytic, provided only that it uses the tools of analytic philosophy. In the substantive model, the tools of analytic philosophy serve a specific kind of theology, theology that is broadly orthodox.

It is easy to see why the tool metaphor is so attractive to analytic theologians. By appealing to the tool metaphor, they can help dispel worries that their philosophical commitments are driving their theological commitments. To say that analytic philosophy is a tool for the theologian is just another way of making the traditional claim that philosophy is the servant of theology. The analytic theologian explicates his already-held theological commitments (whatever they are) using the idiom of analytic philosophy, but he does not acquire any new theological commitments by virtue of that idiom. The Christian tradition has usually treated theology as more fundamental and more comprehensive than philosophy. Theology is the queen of the sciences: philosophy is meant to serve theology, not the other way around. In truth, matters have always been more complicated. Even within theological traditions associated with creedal orthodoxy, exactly what counts as theology or philosophy at any given time varies. Sometimes they are regarded almost as identical, at other times as distinct but mutually supportive, and at still other times, they are sharply opposed. Still, the point remains-on most Christian accounts, theology is that discourse that subsumes all others and is subsumed by none.

There is much to be said for the tool metaphor. There are some kinds of theological work for which analytic tools are especially well-suited, and some kinds for which they are not. Suppose one wants to assess the claim that the traditional Chalcedonian Christology is logically incoherent. Analytic philosophy can help. Logical paraphrase, precise accounts of necessity, possibility, and identity, a sophisticated understanding of essential and nonessential properties: the resources of analytic philosophy are ideally-suited for assessing the formal coherence of Christian truth claims. On the other hand, if you want a thick- 
description of what it is like for Christians to participate in the Eucharist, or to understand the material, historical conditions that shaped its development in (say) the Roman Catholic Church, then analytic philosophy will be less useful. ${ }^{9}$ An elementary point, often overlooked in the perennial battles about theological method: different kinds of intellectual work require different tools.

At the same time, however, the tool metaphor is not without problems. It turns out that it is hard to specify what the "tools and methods" of analytic philosophy actually are. In fact, the best recent studies tend to deny that there are any tools and methods that are distinctive to analytic philosophy. Brian Leiter $(2004$, xv) offers a typically blunt appraisal:

so-called 'analytic' philosophers now include quietists and naturalists; old-fashioned metaphysical philosophers and twentieth-century linguistic philosophers; historians of philosophy and philosophers who show no interest in the history of the field. Given the methodological and substantive pluralism of Anglophone philosophy, 'analytic' philosophy survives, if at all, as a certain style that emphasizes 'logic', 'rigor', and 'argument' — a stylistic commitment that does little to demarcate it, of course, from Kant, Hegel, Descartes, or Aristotle... Prototypical non-analytic figures, like Schopenhauer and Nietzsche, are far clearer (and more beautiful) writers than many of the dominant figures in Anglophone philosophy today" (1112). ${ }^{10}$

Certainly, we should not make the tendentious mistake of insisting that "tools" like clarity, precision, logical coherence ${ }_{2}$ and an awareness of entailment relationships somehow belong to analytic philosophy alone. They do not, even if they are foregrounded in analytic philosophy. Analytic philosophers prize argumentative rigor, and try to tease out the hidden implications of disputed claims, but so do virtually all scholars. Linguists and computer scientists (among many others, of course) also rely on formal logic. Theoretical physicists also appeal to thought-experiments. Mathematicians also appeal to specialized intuitions. The converse to these observations holds as well: many analytic philosophers rarely use formal logic, do not perform thought-experiments, and make no appeals to intuition. In summary, it seems that if by the "tools and methods of analytic philosophy" we mean "tools and methods that are deployed by all and only analytic philosophers" then there are none.

Still, it is easy to overstate this point. We should concede that there are no uniquely analytic tools and methods, or any necessary and sufficient conditions for demarcating analytic philosophy from other forms of inquiry. Opponents sometimes treat this concession as a blow that strikes squarely at the heart of analytic philosophy. After all, isn't analytic philosophy in the business of identifying necessary and sufficient conditions? And if analytic philosophers cannot even demarcate the boundaries of their own discipline, doesn't that show that the whole business is suspect? No. The suggestion that these questions should embarrass analytic philosophers rests on false assumptions about the nature of analytic philosophy. Analytic philosophy cannot be identified with the project of giving necessary and sufficient conditions for the extensions of terms or concepts, and so it

\footnotetext{
${ }^{9}$ The term "thick description" comes from the anthropologist Clifford Geertz's "Thick Description: Toward and Interpretive Theory of Culture" (1973, 3-32).

${ }^{10}$ See also Stroll, 2000, 5; Martinich, A.P. and Sosa, D., eds., 2001, 4; Soames 2003, vol. 1, xii; Preston 2007, Glock 2008.
} 
is not embarrassing that analytic philosophers are unable to give necessary and sufficient conditions for "analytic philosophy" (Sluga 1998, 107; Hylton 1998, 54).

Besides, even if there are no necessary and sufficient conditions for what counts as analytic philosophy, we can easily recognize the difference between analytic and nonanalytic philosophy across a broad range of cases. And even if there are no tools and methods used by all-and-only analytic philosophers, it would be silly to deny that some methods and approaches are seen more commonly in analytic philosophy than in other kinds of philosophical inquiry, let alone in other forms of humanistic inquiry. ${ }^{11}$

\section{Analytic Philosophy as Intellectual Tradition}

Analytic philosophy really is a distinctive form of inquiry, but not because it has any unique, absolutely distinctive tools and methods. Analytic philosophy is a distinctive form of inquiry because it is the product of a shared intellectual culture that has created a distinctive intellectual tradition. Here I would appeal to the thought of Alasdair MacIntyre. According to MacIntyre, an intellectual tradition is:

"an argument extended through time in which certain fundamental agreements are defined and redefined in terms of two kinds of conflict: those with critics and enemies external to the tradition who reject all or at least key parts of those fundamental agreements, and those internal, interpretive debates through which the meaning and rationale of the fundamental agreements come to be expressed and by whose progress a tradition is constituted" $(1989,12) .12$

Analytic philosophy is a robust intellectual tradition in just this sense. It follows that one must be socialized into the tradition of analytic philosophy in order to learn how to use its tools and methods appropriately. Those tools and methods may not be distinctive, but there are distinctively analytic ways to use them.

Analytic philosophy has a history, but it is more than just a historical tradition. It is also a living tradition. Like other such traditions, analytic philosophy is constituted by its specific genealogy and is kept alive by the shared act of reading and discussing specific texts. ${ }^{13}$ To be socialized into the tradition of analytic philosophy, one must learn how to

\footnotetext{
${ }^{11}$ As an attempt to specify what these are, Rea's list of analytic desiderata will do as well as any: "(1) Write as if philosophical positions and conclusions can be adequately formulated in sentences that can be formalized and logically manipulated; (2) Prioritize precision, clarity, and logical coherence; (3) Avoid substantive (nondecorative) use of metaphor and other tropes -whose semantic content outstrips their propositional content; (4) Work as much as possible with well-understood primitive concepts, -and concepts that can analyzed in terms of those; (5) Treat conceptual analysis (insofar as it is possible) as a source of -evidence" (2009, 5-6; see also 17-26).

12 See also Glock 2008, 204-30. I should qualify the claim that analytic philosophy is a tradition in MacIntyre's sense, however. (I don't quite want to go full MacIntyre.) Some of MacIntyre's writings suggest that a tradition is something like a comprehensive world view, and I doubt that analytic philosophy offers anything so grand as that. Moreover, MacIntyre is especially concerned with moral reasoning and the norms of moral evaluation, and the analytic tradition as a whole does not even purport to offer its adherents a comprehensive or internally coherent system of norms for moral evaluation. Even the thriving subfield of analytic ethics does not really offer such a system in the way that MacIntyre understands it. Finally, by calling analytic philosophy an intellectual tradition, and by drawing explicitly on MacIntyre, I do not here mean to affirm or deny that rationality as such is "tradition-bounded" in MacIntyre's sense.

${ }^{13}$ On analytic philosophy as a textual tradition see Shieh and Floyd, eds., 2001, esp. 3-4.
} 
read and what to read, how to argue and what to argue about. One learns to be an analytic philosopher when one learns a particular intellectual vocabulary; one also learns to see specific issues and not others as fruitful intellectual problems, and one learns specific techniques by which those problems should be addressed. More broadly, one learns these practices from one's teachers, who have themselves already been socialized into the analytic tradition. These shared assumptions, methods, and texts allow philosophers to have productive disagreements with one another, because productive disagreements can only arise out of a background of more fundamental agreement. This point is a truism, but it is also the lifeblood of any intellectual tradition.

Analytic philosophers do not tend to think about their field in this way. Although one frequently sees offhand references to "the analytic tradition," for the most part analytic philosophers do not spend much time carefully thinking about the differences between analytic and non-analytic inquiry, still less about what it means to be socialized into a tradition of inquiry. Instead, they just get on with the business of doing philosophy. This is exactly as it should be in a healthy, coherent tradition, but as a consequence, when many analytic philosophers do encounter alien intellectual traditions, they often treat them like deficient forms of analytic philosophy. That is, they do not treat the encounter as a project that requires mutual translation. They do not try to present the analytic tradition in terms that the other will understand, nor do they try to understand the other tradition in its own native terms. The same dialectic often holds from the other side as well: when non-analytic thinkers engage with analytic philosophy they often treat it as a perversely deficient form of what they think inquiry should be. Neither side treats the engagement as a project that requires mutual translation and hermeneutical charity.

\section{Toward Theological Analytic Theology}

Analytic philosophy is not just a method or a set of tools, but a rich, coherent intellectual tradition in its own right. It is this fact that explains why analytic and nonanalytic thinkers often fundamentally misunderstand one another. It is not surprising that those who are well-grounded in the analytic tradition would fail to argue productively with members of non-analytic traditions. Nor is the converse surprising. Both results follow from the tradition-bound nature of analytic inquiry. This account of analytic philosophy has consequences for the emerging field of analytic theology that so far remain unexplored. After all, analytic theology is constitutively inter-disciplinary: it demands mutual translation and cross-border conversation between living intellectual traditions.

At the moment, analytic theologians are typically philosophers of religion by training who have decided to write about Christian doctrinal topics. Analytic philosophy furnishes them with a shared language, rather than just a set of tools and methods. Analytic philosophy is the lingua franca of analytic theologians, the language they use to discuss doctrinal topics across confessional boundaries. For example, two analytic theologians who disagree about, for example, the Eucharist, or the interpretation of the Bible, or the nature of ecclesial authority, can nevertheless work together to assess arguments about those topics, because their assessments can draw on the common language of analytic 
philosophy. The shared language of analytic philosophy allows them to read and comment on each other's work, because it offers a common intellectual vocabulary and common standards of evaluation.

Herein lies the worry. On the traditional understanding, philosophy is meant to be the servant of theology: the theologian's primary tradition and primary intellectual wellspring should always be theology. The worry arises when analytic philosophy remains the only real language of the analytic theologian. It is not difficult to imagine a philosopher of religion who is deeply-grounded in the analytic tradition, but who has a comparatively shallow grasp of theology, the history of Christian thought, and the development of doctrine. In that case, his engagement with theology may well be one-sided, inexpert, and naïve in ways that he himself is not able to recognize. He may not recognize when the conceptual vocabulary and grammar of the Christian tradition differs from his own, superficially similar, analytic vocabulary and grammar. For example, he might assume that the Patristic fathers meant by physis whatever current analytic metaphysicians mean by "nature." Or he might assume that talk of "God beyond Being" is either nonsense or thinlydisguised atheism, without ever investigating what it meant in its original neoplatonistNeoplatonist context. A philosopher who is embedded in the analytic tradition, but not similarly embedded in any tradition of theology, is likely to view theology only through his own narrow disciplinary lenses. He is apt to treat theology as little more than further grist for the analytic mill, a new source of conceptual problems. Analytic theology would then no longer be theology that uses analytic philosophy as a tool. Instead it would be philosophy of religion aimed at specifically Christian puzzles. The traditional relationship between philosophy and theology would be reversed.

I should add that the converse danger is just as real. Theologians without analytic training who wish to deploy the tools and methods of analytic philosophy in their work face a similar burden. A theologian must be embedded in the tradition of analytic philosophy in order to deploy its conceptual resources adeptly. This claim follows from the very idea of membership in an intellectual tradition. Many contemporary theologians can rightly claim full membership of various other philosophical traditions like phenomenology, deconstruction, or critical theory. As such, they can sensitively interpret that tradition's primary texts, and will often be able to contribute constructively to the philosophical tradition itself. When they draw on its resources as theologians, they do so from the inside, as fluent experts. A would-be analytic theologian must be equally grounded in analytic philosophy. The danger is that contemporary theologians who want to do analytic theology will not undertake this work. ${ }^{14}$ It is not easy to learn how to think and write like an analytic philosopher.

There is only one way for analytic theologians to avoid these dangers. They must become a fluent member of two traditions, and learn to speak the "languages" of both analytic philosophy and Christian theology with ease. Only then can analytic theologians be faithful to both parts of their self-avowed moniker. Only then can they avoid misrepresenting either the Christian tradition, on the one hand, or the analytic tradition on the other. This task is challenging, but no more challenging than the task of becoming a good historian of philosophy. A good historian of philosophy is similarly bilingual. She

\footnotetext{
${ }^{14}$ And a related danger, that theologians will criticize analytic philosophy or analytic theology without taking the time to understand it properly, is even more real.
} 
understands the great philosophers of the past as they understood themselves, in their native, often-alien, conceptual idiom, even as she also assesses those philosophers in a current idiom with current standards of rigor. Analytic theologians should be similarly expert in analytic philosophy, while remaining, above all, theologians grounded in the Christian tradition.

Becoming suitably grounded in the Christian intellectual tradition is itself a difficult task. It is not just a matter of understanding the surface meaning of the words of the creeds, recognizing some major heresies, and having some minimal grasp of the development of doctrine. (By way of comparison, philosophers should consider whether someone trained in theology is likely to be able to make a high-level scholarly contribution to analytic metaphysics just because he has done some self-directed reading of Quine, Kripke, and Lewis.) To return to the guiding metaphor, if philosophy presents the theologian with intellectual tools, only a full member of the analytic tradition will know how to use analytic tools expertly. At the same time, only a suitably expert theologian will know how to use analytic tools to construct an edifice worth inhabiting.

Analytic theologians should also deepen their own engagement with contemporary academic theology. I suspect that many analytic theologians will resist this claim. It is one thing to ask that they be well-grounded in the Christian tradition. It is quite another to insist that they be au fait with all the bewildering intra-disciplinary disputes of contemporary academic theology. Analytic theologians ask perennial, fundamental questions about the coherence and truth of the Christian faith. They do not focus on whatever hot topics currently preoccupy specialist academic theologians. To demand that analytic theologians be fully-paid up members of the guild of academic theology is to close off the possibility that they might offer fruitful interventions from outside that guild.

Fair enough. But any constructive theologian, analytic or otherwise, must do more than simply mine the historical tradition for antecedents and opponents of his own present-day views. An analytic theologian who wants nothing to do with contemporary academic theology will rightly invite questions about just what kind of scholarly intervention he takes himself to offer. One can hardly hope to influence contemporary theology without engaging it directly, after all, and that means reading it carefully and taking its current preoccupations seriously. One can only speak to theologians by addressing the concerns that they actually have. The Christian tradition as a whole is a living tradition, and theology-including academic theology-is its ongoing conversation. In order to participate in that conversation fully, one must listen to its contemporary speakers.

So far, with notable exceptions, the analytic engagement with academic theology has been minimal. ${ }^{15}$ If this trend continues, I worry that analytic theology will not find an institutional home in the contemporary academy. Without an institutional home, it will wither on the vine. At the moment, analytic theology primarily happens in the philosophy departments of religiously affiliated universities and in evangelical seminaries. I doubt that this situation is stable in the long-term; certainly-it certainly does not seem like a basis for growth. More to the point, however, when analytic theologians remain confined to philosophy departments, they will inevitably find that philosophers are their primary

\footnotetext{
${ }^{15}$ One notable exception is Diller 2014, which is a very fine example of an analytic engagement with a major current of contemporary theology.
} 
interlocutors, with the resulting danger that their own intellectual engagement with the Christian tradition will be comparatively shallow. Without realizing it, they will treat the Christian tradition instrumentally, as a novel source of puzzles to be solved, rather than as the living water of their own intellectual formation.

\section{Bibliography}

Crisp, Oliver, ed. 2009. A Reader in Contemporary Philosophical Theology. Continuum.

Crisp, Oliver, and Rea, Michael, eds. 2009. Analytic Theology: New Essays in the Philosophy of Theology. Oxford University Press.

Cross, Richard. 2010. Review of Crisp and Rea, eds., Analytic Theology. International Journal of Systematic Theology 12: 452-463.

Diller, Kevin. 2014. Theology's Epistemological Dilemma: How Karl Barth and Alvin Plantinga Provide a Unified Response. InterVarsity Press.

Feenstra Ronald J., and Plantinga, Jr. Cornelius, eds. 1989. Trinity, Incarnation, and Atonement: Philosophical and Theological Essays. University of Notre Dame Press.

Geertz, Clifford. 1973. The Interpretation of Cultures. Basic Books.

Glock, Hans-Johann. 2008. What is Analytic Philosophy?:; Cambridge University Press.

Graham, Gordon. 2009. Review of Crisp and Rea, eds., Analytic Theology. Notre Dame Philosophical Reviews. https://ndpr.nd.edu/news/24074-analytic-theology-newessays-in-the-philosophy-of-theology/

Hasker, William. 2013. Metaphysics and the Tripersonal God. Oxford University Press.

Hylton, Peter. 1998. "Analysis in Analytic Philosophy" in Anat Biletzki and Atat Matar, The Story of Analytic Philosophy: Plot and Heroes. Routledge.

Jacobs, Jonathan. 2015. "The Ineffable, Inconceivable, and Incomprehensible God: Fundamentality and Apophatic Theology." Oxford Studies in Philosophy of Religion. DOI: http://dx.doi.org/10.1093/acprof:oso/9780198722335.003.0007

Leiter, Brian, ed. 2004. The Future for Philosophy. Oxford University Press.

MacIntyre, Alasdair. 1989. Whose Justice? Which Rationality?. University of Notre Dame Press.

Marmodoro, Anna, and Hill, Jonathan, eds. 2011. The Metaphysics of the Incarnation. Oxford 


\section{University Press.}

Martinich, A.P. and Sosa, D., eds. 2001. A Companion to Analytic Philosophy. Blackwell.-

McCall, Thomas H. 2010. Which Trinity? Whose Monothesim? Continuum.

Oliver, Simon. 201. Review of Crisp and Rea, eds., Analytic Theology. International Journal of Systematic Theology 12: 464-475.

Preston, Aaron. 2007. Analytic Philosophy: The History of an Illusion. Continuum.

Rea, Michael, ed. 2009. Oxford Readings in Philosophical Theology. 2 vols. Oxford University Press.

Shieh, Sanford, and Floyd, Juliet, eds. 2001. Future Pasts: The Analytic Tradition in Twentieth-Century Philosophy. Oxford University Press.

Sluga, Hans. 1998. “Critical notice of Hacker's 'What Has History to Do with Me? Wittgenstein and Analytic Philosophy.' Inquiry 41 (11): 99-121.

Soames, Scott. 2003. Philosophical Analysis in the Twentieth Century. 2 vols. Princeton University Press.-

Stroll, Avrum. 2000. Twentieth Century Analytic Philosophy. Columbia University Press.

Williamson, Timothy. 2014. "How Did We Get Here From There? The Transformation of Analytic Philosophy." Belgrade Philosophical Annual 27: 7-37.

Wood, William. 2009. "On the New Analytic Theology: The Road Less Travelled." Journal of the American Academy of Religion 77: 941-960. 